\title{
Seasonal differences in the content of Oikopleura vanhoeffeni and Calanus finmarchicus faecal pellets: illustrations of zooplankton food web shifts in coastal Newfoundland waters
}

\author{
Juanita L. Urban ${ }^{1,2, *}$, Cynthia H. McKenzie ${ }^{1}$, Don Deibel ${ }^{1,2}$ \\ ${ }^{1}$ Ocean Sciences Centre, ${ }^{2}$ Department of Biology, Memorial University of Newfoundland, St. John's, \\ Newfoundland, Canada A1C 5S7
}

\begin{abstract}
Faecal pellet contents from Oikopleura vanhoeffeni and Calanus finmarchicus were examined in the spring, summer, fall and winter. Contents varied seasonally, resembling available particles in the water column. This indicated a temporal succession from a diatom-based food chain in the winter and spring to one based on the microbial loop in the summer and fall. Bacteria, cyanobacteria, Anabaena sp., choanoflagellates, ciliates, and heterotrophic dinoflagellates were found in the faeces, suggesting a direct link between the microbial loop and both crustaceans and pelagic tunicates.
\end{abstract}

\section{INTRODUCTION}

Primary production by phytoplankton and bacteria forms the basis of all aquatic food webs. Composition of the phytoplankton community in coastal, temperate waters varies seasonally, from a predominance of large, chain-forming diatoms in the winter and spring to dinoflagellates, protozoans and nanoplankton in the summer and early fall (Smayda 1980, Marshall \& Cohn 1983, Marshall 1984, Veldhuis et al. 1988, Nielsen \& Richardson 1989). This results in a succession from a diatom-based food chain in the winter and spring to one based on the 'microbial loop' in the summer and fall. However, interactions between phytoplankton, bacteria, protozoans and zooplankton are not well understood. How and to what extent are microbial food webs linked to metazoans? Are small plankton energy links (i.e. prey) or sinks (i.e. decomposers)? Does the nature of this linkage vary seasonally in coastal Newfoundland, Canada, waters that are dominated by the sub-arctic Labrador current?

\footnotetext{
- Present address: Horn Point Environmental Laboratory, University of Maryland, Cambridge, Maryland 21613, USA.
}

Primary production in many oceanic and coastal areas is dominated annually by nanoplankton (2 to $20 \mu \mathrm{m}$ ) and picoplankton $(<2 \mu \mathrm{m}$ ) (Booth et al. 1982, Murphy \& Haugen 1985, Hoepffner \& Haas 1990). It is known that copepods and euphausiids are not able to feed efficiently on particles $<10 \mu \mathrm{m}$ in size (Marshall \& Orr 1955, Nival \& Nival 1976, Fenchel 1988), and that protozoan consumers, such as ciliates and choanoflagellates, may consume 4 to $70 \%$ of the annual algal production (references in Burkill et al. 1987). These observations suggest that most of the primary production is recycled in the upper mixed layer (i.e. through the microbial loop), and that only large phytoplankton $>20 \mu \mathrm{m}$ in size contribute to nutrient flux out of the euphotic zone. However, mucous-net feeders, such as salps, doliolids and appendicularians, ingest nanoplankton and picoplankton efficiently (Harbison \& McAlister 1979, Mullin 1983, Deibel \& Lee 1992), thereby creating a means through faeces of transporting the organisms out of the euphotic zone (Michaels \& Silver 1988).

The purpose of this study was to examine, using scanning electron microscopy, how phytoplankton content of faeces from Calanus finmarchicus, a raptorial, suspension-feeding copepod, and Oikopleura vanhoeffeni, a pelagic tunicate that feeds with a mucous filter, varies 
seasonally. This paper reports on a descriptive study, ilustrating seasonal changes in faecal pellet contents. The content of the faeces determines their primary density and nutrient content (Urban et al. in press). Also, it provides information on the structure of the zooplankton food web and on the seasonally changing role of different organisms in energy flow.

\section{MATERIALS AND METHODS}

Oikopleura vanhoeffeni was collected in $400 \mathrm{ml}$ glass jars by SCUBA divers in March, June and November 1990, and January 1991, from Logy Bay, insular Newfoundland, Canada. Immediately after collection the jars were placed in a flow-through seawater bath in the laboratory. After a period of 1 to $12 \mathrm{~h}$ the houses were shaken to release pellets trapped inside. The house and animal were then removed and the remaining water was poured through a $20 \mu \mathrm{m}$ nitex filter to collect pellets.

Fresh, intact pellets were removed from the filter and pipetted into a beaker with distilled water. This water containing the pellets was then passed through a $0.45 \mu \mathrm{m}$ nylon filter $(13 \mathrm{~mm}$ in diameter, Micron Separations Inc., Westboro, MA, USA ). The filter with attached pellets was put through an ethanol dehydration series $(50 \%, 70 \%, 85 \%, 95 \%, 100 \%)$, and criticalpoint dried (Turner 1984). After critical-point drying, $50 \%$ of the pellets were pulled in half using doublesided tape before being mounted and coated with gold. Pellet contents were viewed on a Hitachi S 570 scanning electron microscope (SEM) with the upper detector set at $15 \mathrm{kV}$ and an $8 \mathrm{~mm}$ working distance.

Calanus finmarchicus was collected from Conception Bay, Newfoundland, in April, July and September 1990, from oblique hauls with a $0.5 \mathrm{~m}$ plankton net fitted with $350 \mu \mathrm{m}$ nylon mesh (Nitex) and a closed cod end cup. The net was lowered to $200 \mathrm{~m}$, towed for $1 \mathrm{~min}$, and then retrieved at a rate of $13 \mathrm{~m} \mathrm{~min}^{-1} \mathrm{Cod}$ end contents were emptied into a bucket containing water from the subsurface chlorophyll maximum (SCM). Within 3 h, adult $C$. finmarchicus females were removed from the bucket and placed in a large PVC cup with a bottom of $505 \mu \mathrm{m}$ nitex mesh. The cup was suspended in a bucket containing water from the SCM and incubated in the laboratory at ambient seawater temperature $\left(-1\right.$ to $10^{\circ} \mathrm{C}$ ) for 1 to $12 \mathrm{~h}$. At the end of the incubation period the PVC cup was removed from the bucket and the water was passed through $20 \mu \mathrm{m}$ nitex mesh to collect all faecal pellets. Pellets were removed from the filter by pipet and prepared for SEM as above for Oikopleura vanhoeffeni.

In each season, 6 to 8 faecal pellets from both Calanus finmarchicus and Oikopleura vanhoeffeni were examined at $3000 \times$ using SEM. 3000 to 5000 fields were scanned on $O$, vanhoeffeni pellets (average pellet area was $9.73 \times 10^{5} \mu \mathrm{m}^{2}$ ), and 500 to 700 fields were scanned on $C$. finmarchicus pellets (average pellet area was $1.42 \times 10^{5} \mu \mathrm{m}^{2}$ ). Photomicrographs were made of all phytoplankton species that appeared in $>20 \%$ of the fields and of those that were unique or rare. Intact cells were measured to the nearest $0.1 \mu \mathrm{m}$, and were identified to genus and/or species when possible. Taxa that appeared in $>50 \%$ of the fields were tabulated as 'abundant', those that appeared in 20 to $50 \%$ as 'common', and those that appeared in $<20 \%$ 'rare'.

When Calanus finmarchicus was collected, $180 \mathrm{ml}$ samples were taken from the SCM for floristic analysis. Cell samples were stained with Lugol's iodine and fixed in $5 \%$ borate-buffered formaldehyde in seawater. 10 to $50 \mathrm{ml}$ samples were allowed to settle for $48 \mathrm{~h}$, followed by identification and counting at 20 and $40 \times$ using a Zeiss Axiovert 35 inverted microscope with phase contrast. The whole slide was viewed at $20 \times$ and all cells $>20 \mu \mathrm{m}$ were counted, except in April where 2 across-diameter tracks allowed for more than 200 cells to be counted. Two across-diameter tracks were counted at $40 \times$ for cells $<20 \mu \mathrm{m}$, with a total of $\geq 200$ cells counted per sample (Utermöhl 1958).

\section{RESULTS}

A complete species list of the contents identified from the faecal pellets of Calanus finmarchicus and Oikopleura vanhoeffeni is given in Tables $1 \& 2$. The contents for both faecal pellet types followed similar seasonal variations. Direct comparisons between the contents of the faeces for the 2 species of zooplankters cannot be made since they were collected at different times and from different sites.

\section{Spring}

In March, Oikopleura vanhoeffeni faeces were filled with diatoms (Fig. 1) and chrysophytes (Fig. 2). Dinoflagellates, silicoflagellates, coccolithophorids, choanoflagellates, ciliates and bacteria were 'rare' Many cells were intact and diatom chains were observed. Cells ranged from 0.7 to $183 \mu \mathrm{m}$ in least dimension in valve view, with most $<10 \mu \mathrm{m}$ in size.

In April, broken diatom frustules (Fig. 3) dominated the contents of Calanus finmarchicus faeces, including Skeletonema costatum (Fig. 4), Chaetoceros spp., Thalassiosira spp. and Fragillariopsis spp. Intact cells ranged from 5 to $18 \mu \mathrm{m}$ in least dimension. Chrysophyte and dinoflagellate remains were 'rare' 
Table 1. Oikopleura vanhoeffeni. Phytoplankton content of faecal pellets. a: Abundant, found in $>50 \%$ of fields viewed; c: common, found in 20 to $50 \%$; r rare, found in $<20 \%$.

- Fragments identified by plate or surface morphology

\begin{tabular}{|c|c|c|c|c|}
\hline Species & Spring & Summer & Fall & Winter \\
\hline \multicolumn{5}{|l|}{ Bacillariophyceae } \\
\hline Amphora spp. & $\mathrm{r}$ & & & $\mathrm{r}$ \\
\hline Arcocellulus cornucervis & a & & c & a \\
\hline Bacterosira ragelis & & & $\mathrm{r}$ & \\
\hline Berkeleya sp. & $\mathrm{r}$ & & & \\
\hline Chaetoceros spp. & & $\mathrm{c}$ & & a \\
\hline Cocconeis spp. & $\mathrm{r}$ & $\mathrm{r}$ & $\mathrm{C}$ & c \\
\hline Coscinodiscus radiatus & a & & & \\
\hline Cyclotella spp. & & & $\mathrm{r}$ & \\
\hline $\begin{array}{l}\text { Fragillariopsis spp. } \\
\quad \text { F. curvata } \\
\text { F. cylindrus }\end{array}$ & a & & c & a \\
\hline Gomphoneopis littoralis & & c & $\mathrm{r}$ & \\
\hline $\begin{array}{l}\text { Gomphoseptatum } \\
\text { aestuarrii }\end{array}$ & c & & $r$ & \\
\hline Licmophora sp. & c & & & $\mathrm{r}$ \\
\hline Minidiscus trioculatus & $\mathrm{a}$ & & a & c \\
\hline Navicula spp. & c & $\mathrm{c}$ & c & c \\
\hline Nitzschia sp. & $\mathrm{r}$ & & & \\
\hline Pleurosigma sp. & $\mathrm{r}$ & & & \\
\hline $\begin{array}{l}\text { Pseudogomphonema } \\
\text { kamtschaticum }\end{array}$ & c & & & \\
\hline Pteroncola spp. & c & & a & \\
\hline Skeletonema costatum & a & & a & a \\
\hline Tabularia sp. & $\mathrm{r}$ & c & c & \\
\hline $\begin{array}{c}\text { Thalassionema } \\
\text { nitzschioides }\end{array}$ & & & $\mathrm{r}$ & c \\
\hline $\begin{array}{l}\text { Thalassiosira spp. } \\
\text { T. gravida } \\
\text { T. minima } \\
\text { T. pseudonana } \\
\text { T. symmetrica }\end{array}$ & c & a & c & c \\
\hline \multicolumn{5}{|l|}{ Pyrrhophyceae } \\
\hline Ceratium sp. & & & $\mathrm{r}$ & \\
\hline Gymnodinium sp. & & & $\mathrm{r}$ & \\
\hline $\begin{array}{l}\text { Prorocentrum spp. } \\
\text { P. balticum } \\
\text { P. minima }\end{array}$ & c & & a & c \\
\hline $\begin{array}{l}\text { Protoperidinium spp. } \\
\text { P depressum }\end{array}$ & & $\Gamma$ & & \\
\hline Scrippsiella sp. & & & a & \\
\hline \multicolumn{5}{|l|}{ Chrysophyceae } \\
\hline $\begin{array}{l}\text { Dictyocha } \\
\text { speculum }\end{array}$ & $c$ & & c & $r$ \\
\hline Tetraparma sp. & a & & I & I \\
\hline Triparma stigata & $\mathrm{r}$ & & & $r$ \\
\hline \multicolumn{5}{|l|}{ Xanthophyceae } \\
\hline $\begin{array}{c}\text { Meringosphaera } \\
\text { mediterranea }\end{array}$ & & & a & c \\
\hline \multicolumn{5}{|l|}{ Haptophyceae } \\
\hline Coccolithus pelagicus & $r$ & & r & $r$ \\
\hline Emiliana huxeleyi & $c$ & & a & a \\
\hline \multicolumn{5}{|l|}{ Craspedophyceae } \\
\hline $\begin{array}{l}\text { Parvicorbicula sp. } \\
\text { Stephanoeca sp. }\end{array}$ & $r$ & & $r$ & \\
\hline - Lorica bundles & $\mathrm{r}$ & & $\mathrm{a}$ & a \\
\hline \multicolumn{5}{|l|}{ Tintinnina } \\
\hline Stenosemella steini & c & & & \\
\hline \multicolumn{5}{|l|}{ Others } \\
\hline Bacteria & c & $\mathrm{r}$ & c & c \\
\hline Ciliates & & & $\mathrm{c}$ & $\mathrm{r}$ \\
\hline Cysts & $\mathrm{r}$ & $\mathrm{r}$ & a & $\mathrm{r}$ \\
\hline Euglenoids & c & & $\mathrm{c}$ & \\
\hline
\end{tabular}

Table 2. Calanus finmarchicus. Phytoplankton content of faecal pellets. a: Abundant, found in $>50 \%$ of fields viewed; c: common, found in 20 to $50 \%$; r: rare, found in $<20 \%$ of fields viewed. "Fragments identified by plate or surface morphology

\begin{tabular}{|c|c|c|c|}
\hline Species & Spring & Summer & Fall \\
\hline \multicolumn{4}{|l|}{ Bacillariophyceae } \\
\hline Amphora spp. & & & $\mathrm{r}$ \\
\hline Chaetoceros spp. & a & r & \\
\hline Cocconeis spp. & & $\mathrm{r}$ & $\mathrm{r}$ \\
\hline Minidiscus trioculatus & & & $\mathrm{r}$ \\
\hline Navicula spp. & & & $\mathrm{r}$ \\
\hline Nitzschia sp. & r & & \\
\hline Skeletonema costatum & a & & \\
\hline $\begin{array}{l}\text { Thalassiosira spp. } \\
\text { T. gravida } \\
\text { T. minima } \\
\text { T. pseudonana } \\
\text { T symmetrica }\end{array}$ & a & c & \\
\hline \multicolumn{4}{|l|}{ Pyrrhophyceae } \\
\hline - Ceratium sp. & & & $\mathrm{r}$ \\
\hline Gymnodinium sp. & & & $\mathrm{r}$ \\
\hline $\begin{array}{l}\text { Prorocentrum spp. } \\
\text { P. balticum } \\
\text { P. minima }\end{array}$ & $r$ & c & c \\
\hline \multicolumn{4}{|l|}{ Chrysophyceae } \\
\hline Tetraparma sp. & $\mathrm{r}$ & & \\
\hline $\begin{array}{l}\text { Craspedophyceae } \\
\text {-Lorica bundles }\end{array}$ & & c & a \\
\hline \multicolumn{4}{|l|}{ Others } \\
\hline Bacteria & I & $\mathrm{r}$ & a \\
\hline Ciliates & & & a \\
\hline Cyanobacteria & & $\mathrm{r}$ & c \\
\hline Cysts & & $\mathrm{r}$ & a \\
\hline
\end{tabular}

The water sample was dominated by diatoms, primarily Thalassiosira spp. and Chaetoceros spp. (Table $3)$. Unidentifiable spheres $<2 \mu \mathrm{m}$ in diameter were copious, followed by choanoflagellates and chrysophytes. Ciliates and dinoflagellates were scarce. Total cell number was $1.58 \times 10^{6} \mathrm{l}^{-1}$.

\section{Summer}

Broken and unidentifiable diatom frustules dominated faecal pellet contents of Oikopleura vanhoeffeni in the end of May and beginning of June (Fig. 5). Individual cells ranged from 1 to $167 \mu \mathrm{m}$ in least dimension in valve view. Dinoflagellate fragments were 'common' (Figs. $6 \& 7$ ).

In the end of June and early July, the pellet contents of Calanus finmarchicus were diverse. Broken diatom frustules were 'abundant' (Fig. 5), but bacteria, choanoflagellates (Fig. 8), cyanobacteria (Anabaena sp.), dinoflagellates (Fig. 6), and diatom cysts were 'common'. Intact cells ranged from 1 to $44 \mu \mathrm{m}$ in least dimension.

Particles in the water were dominated by macroscopic flocs of 'marine snow' (Table 3). Few intact diatoms were present. Spheres $<2 \mu \mathrm{m}$ in diameter 

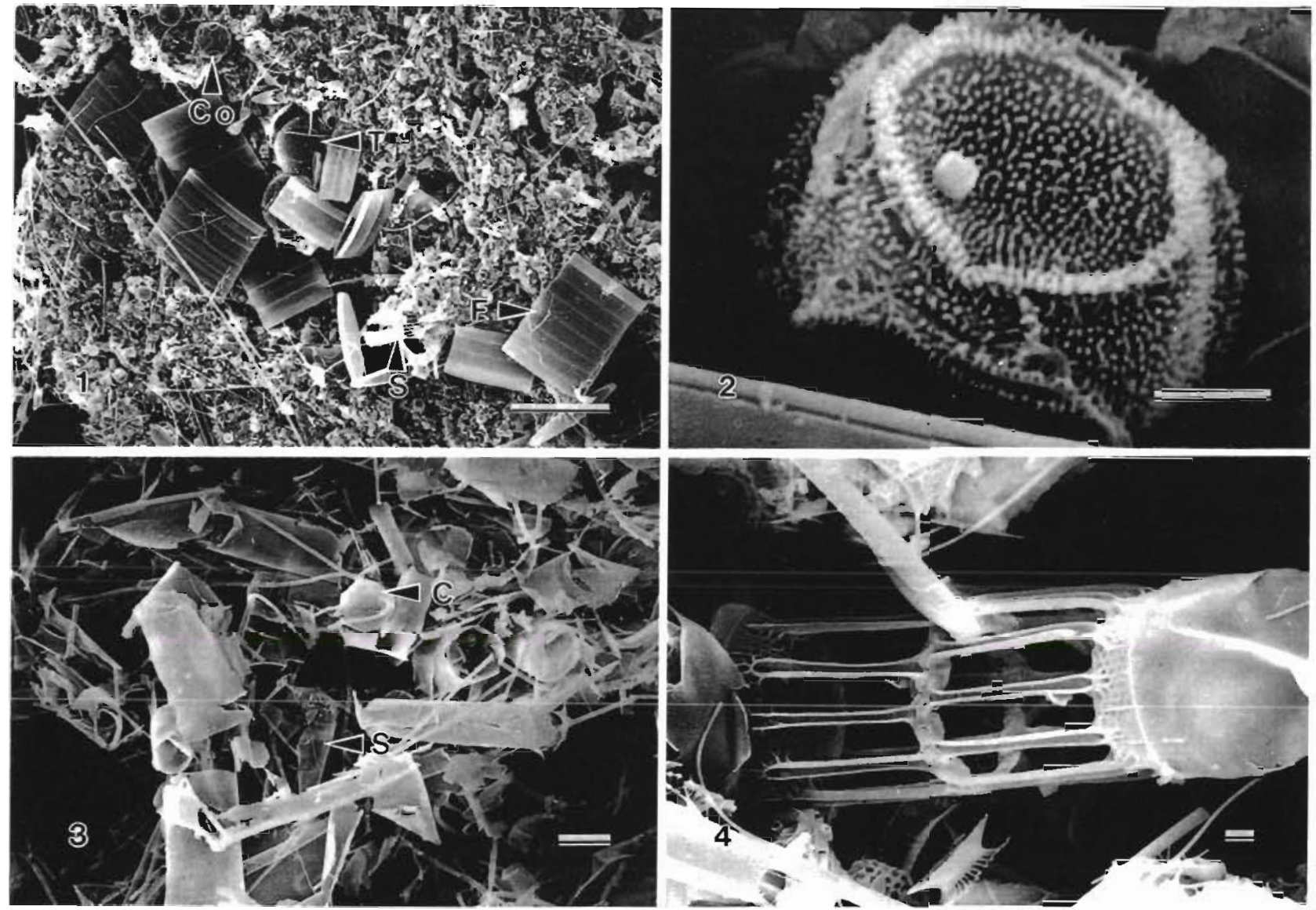

Figs. 1 to 4 . Oikopleura vanhoeffeni and Calanus finmarchicus. Spring faecal content. Fig. 1. O. vanhoeffeni. Overview of faecal pellet. F: Fragillariopsis sp. chain; $\mathrm{Co}$ : coccolithophore $\mathrm{S}_{\mathrm{S}}$ Skeletonema costatumi $\overline{\mathrm{T}}$ : Thalassiosira sp. Scale bar $=20 \mu \mathrm{m}$. Fig. 2. Tetraparma sp., common chrysophyte. Scale bar $=1 \mu \mathrm{m}$. Fig. 3. C. finmarchicus. Overview of faecal pellet. C: Chaetoceros $\mathrm{sp}$; S. Skeletonema sp. Scale bar $=5 \mu \mathrm{m}$. Fig. 4. Skeletonema costatum, a dominant diatom. Scale bar $=1 \mu \mathrm{m}$

were the most prevalent live organisms. Gymnodinium spp., choanoflagellates and ciliates were present. Total cell number was $1.91 \times 10^{5} \mathrm{l}^{-1}$.

\section{Fall}

In September, Calanus finmarchicus faeces were dominated by nanoplankton, including ciliates (Fig. 9), bacteria, cyanobacteria (Fig. 10), choanoflagellates (Fig. 11), unidentifiable cysts, cryptomonads, dinoflagellates and chrysophytes. Cells ranged from 0.5 to $87 \mathrm{um}$ in least dimension. Small diatoms were 'rare'.

Chrysophytes and unidentifiable spheres $<2 \mu \mathrm{m}$ in diameter dominated the cells in the SCM (Table 3). Small ( $<15 \mu \mathrm{m}$ ) and large ( $>20 \mu \mathrm{m}$ ) ciliates were plentiful, as were choanoflagellates, gymnodinoid dinoflagellates and marine snow. Total cell abundance was $3.13 \times 10^{5} \mathrm{l}^{-1}$ In November, diverse nanoplankton species domi- nated the faecal pellets of Oikopleura vanhoeffeni. Dinoflagellates (Fig. 12), silicoflagellates (Fig. 13), euglenoids (Fig. 14), chrysophytes, xanthophytes (Fig. 15), diatoms and coccolithophorids (Fig. 16) were 'abundant', with many partially broken cells. Intact cells ranged from 0.9 to $57 \mu \mathrm{m}$ in least dimension.

\section{Winter}

Diatoms, including Skeletonema costatum, Chaetoceros spp. (Fig. 17) and Arcocellulus cornucervis (Fig. 18), and coccolithophorids (Fig. 19) were the main components in the faecal pellets of Oikopleura vanhoeffeni in January. Chrysophytes, dinoflagellates, choanoflagellates and ciliates were 'common' (Fig. 20). Small cells appeared to be intact but many larger cells and chain-forming diatoms were cracked. Intact cells ranged from 1 to $66 \mu \mathrm{m}$ in least dimension, 
Table 3. Cell counts (cells $\mathrm{l}^{-1}$ ) and $\%$ of total in water samples from Conception Bay. Total does not include marine snow; " none present in sample

\begin{tabular}{|c|c|c|c|}
\hline Plankton category & Spring, 6 Apr 1990 & Summer, 26 Jun 1990 & Fall, 27 Sep 1990 \\
\hline Total cell count & $1.58 \times 10^{6}$ & $1.91 \times 10^{5}$ & $3.13 \times 10^{5}$ \\
\hline$<2 \mu \mathrm{m}$ spheres & $2.95 \times 10^{5} \quad(19 \%)$ & $1.07 \times 10^{5}$ & $8.24 \times 10^{4}$ \\
\hline $2-5 \mu \mathrm{m}$ spheres & $3.23 \times 10^{4} \quad(2 \%)$ & . & . \\
\hline$>5 \mu \mathrm{m}$ spheres & $8.08 \times 10^{3} \quad(0.5 \%)$ & $1.21 \times 10^{4}$ & $1.03 \times 10^{5}$ \\
\hline Chrysophytes & $6.46 \times 10^{4} \quad(4 \%)$ & $1.45 \times 10^{4}$ & $4.85 \times 10^{4}$ \\
\hline Choanoflagellates & $6.26 \times 10^{4}$ & $1.06 \times 10^{4}$ & $4.04 \times 10^{3}$ \\
\hline Cryptophytes & $2.22 \times 10^{4} \quad(1 \%)$ & $5.39 \times 10^{3}$ & $4.04 \times 10^{3}$ \\
\hline Cyanobacteria & $2.02 \times 10^{3} \quad(0.1 \%)$ & $1.62 \times 10^{3}$ & $4.04 \times 10^{3}$ \\
\hline Phaeocystis sp. & $2.50 \times 10^{3} \quad(0.2 \%)$ & .. & .. \\
\hline Prasinophytes & $8.08 \times 10^{3} \quad(0.5 \%)$ & $1.62 \times 10^{3}$ & $8.08 \times 10^{2}$ \\
\hline Prymnesiophytes & $2.42 \times 10^{4} \quad(2 \%)$ & $6.47 \times 10^{3}$ & $4.85 \times 10^{3}$ \\
\hline$<20 \mu \mathrm{m}$ ciliates & .. & $8.08 \times 10^{2}$ & $8.08 \times 10^{3}$ \\
\hline$>20 \mu \mathrm{m}$ ciliates & $1.41 \times 10^{4} \quad(0.9 \%)$ & $1.24 \times 10^{3} \quad(0.6 \%)$ & $2.00 \times 10^{2}$ \\
\hline Tintinnids & .. & $8.00 \times 10^{1} \quad(0.04 \%)$ & $2.00 \times 10^{1} \quad(0.006 \%)$ \\
\hline Diatoms & $9.96 \times 10^{5} \quad(63 \%)$ & $5.55 \times 10^{3} \quad(3 \%)$ & $1.05 \times 10^{4} \quad(4 \%)$ \\
\hline Unarmored dinoflagellates & $4.24 \times 10^{4} \quad(3 \%)$ & $2.10 \times 10^{4}$ & $1.62 \times 10^{4}$ \\
\hline Armored dinoflagellates & $1.01 \times 10^{4} \quad(0.6 \%)$ & $2.42 \times 10^{3}$ & $3.33 \times 10^{3}$ \\
\hline Marine snow & .. & $1.10 \times 10^{5}$ & $2.34 \times 10^{4}$ \\
\hline
\end{tabular}
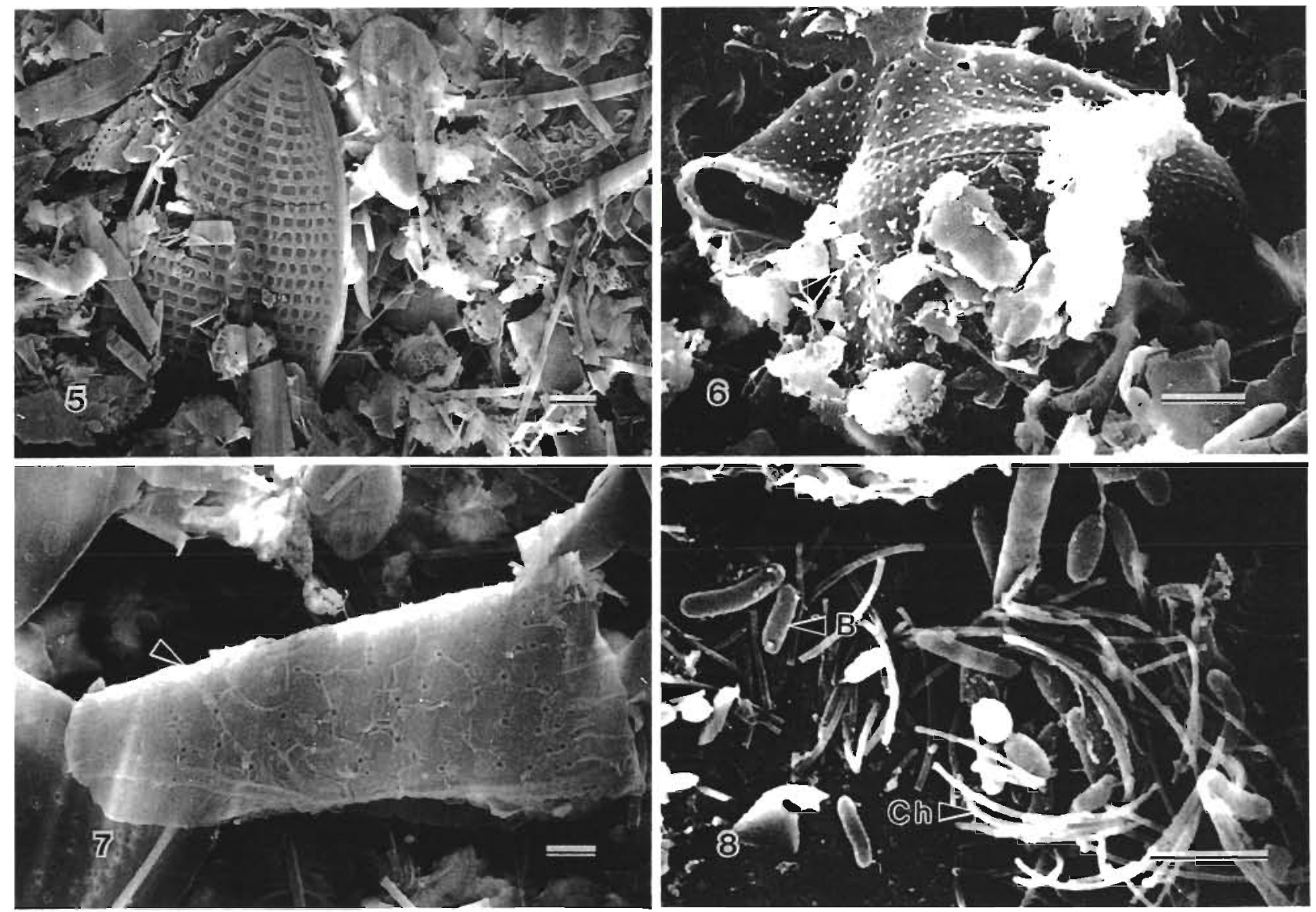

Figs. 5 to 8. Oikopleura vanhoeffeni and Calanus finmarchicus. Summer faecal content. Fig. 5. Broken diatoms, common to both faeces types. Scale bar $=2 \mu \mathrm{m}$. Fig. 6. Prorocentrum sp., dinoflagellate. Scale bar $=2 \mu \mathrm{m}$. Fig. 7 . Protoperidinium depressum, dinoflagellate (arrow). Scale bar $=2 \mu \mathrm{m}$. Fig. 8. B: bacteria; Ch: choanoflagellate remains. Scale bar $=2 \mu \mathrm{m}$ 

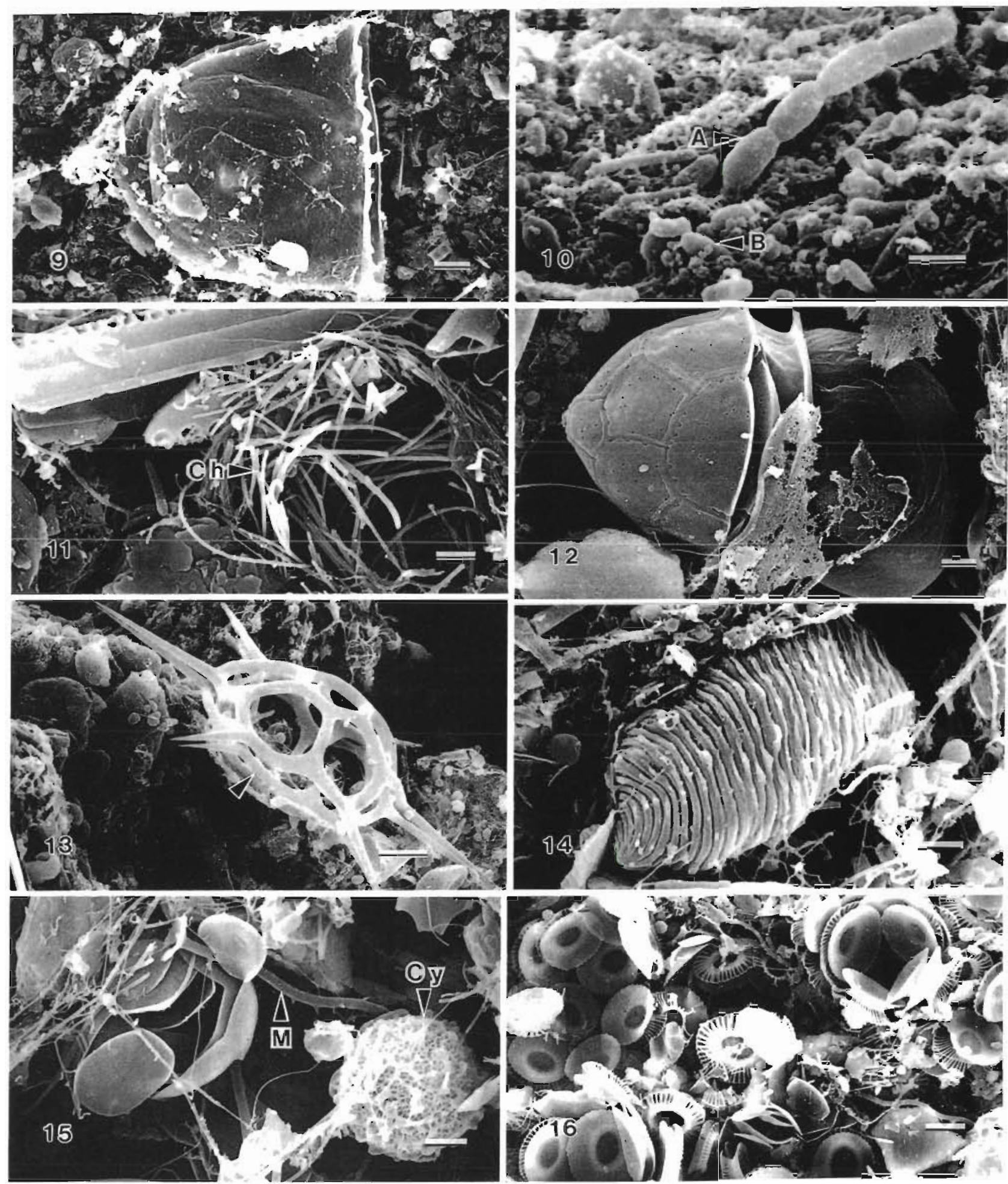

Figs. 9 to 16. Oikopleura vanhoeffeni and Calanus finmarchicus. Fall faecal contents. Fig. 9. Tintinnid. Scale bar $=5 \mu m$. Fig. 10. C. finmarchicus faecal pellet overview. B: bacteria; A: Anabeana sp., a cyanobacteria. Scale bar $=1 \mu \mathrm{m}$. Fig. $11 . \mathrm{Ch}$ : choanoflagellate remains. Scale bar $=1 \mu \mathrm{m}$. Fig. 12. Common dinoflagellate. Scale bar $=2 \mu \mathrm{m}$. Fig. 13. Silicoflagellate (arrow). Scale bar $=5 \mu \mathrm{m}$. Fig. 14. Euglena sp. Scale bar $=1 \mu \mathrm{m}$. Fig. 15. Cy: unknown cyst; $\mathrm{M}: M$. meditterranea. Scale bar $=1 \mu \mathrm{m}$. Fig. 16. O. vanhoeffeni faecal pellet overview. E. huxelyi, coccolithophore. Scale bar $=2 \mu \mathrm{m}$ 


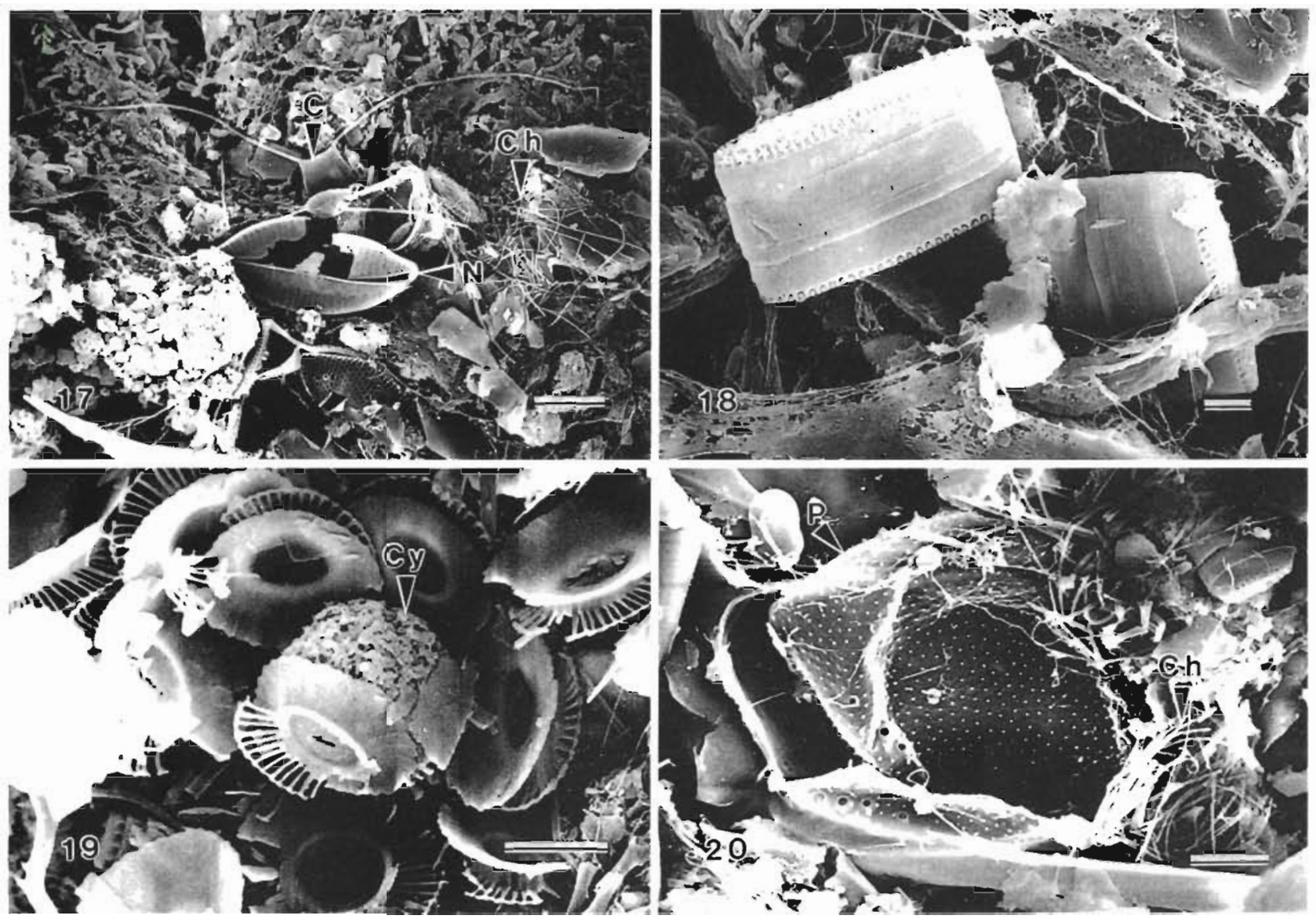

Figs. 17 to 20. Oikopleura vanhoeffeni. Winter faecal contents. Fig. 17. O. vanhoeffeni faecal pellet overview. C: Chaetoceros sp.; $\mathrm{N}$ : Navicula sp.; Ch: choanoflagellate lorica. Scale bar $=5 \mu \mathrm{m}$. Fig. 18. Arcocellulus cornucervis, common diatom. Scale bar $=$ $2 \mu \mathrm{m}$. Fig. 19. Coccolithophore with a cyst (Cy). Scale bar $=2 \mu \mathrm{m}$. Fig. 20. P: Prorocentrum sp., dinoflagellate; Ch: choanoflagellate remains. Scale bar $=2 \mu \mathrm{m}$

\section{DISCUSSION}

\section{Causes of seasonal differences in faecal pellet} content

A seasonal succession of phytoplankton and microbes occurs in coastal Newfoundland waters (Hollibaugh \& Booth 1981, McKenzie unpubl.). Large, chain-forming diatoms dominate phytoplankton biomass and numbers during the spring bloom in Newfoundland waters (Table 3). These autotrophic species deplete dissolved silica in surface waters by the end of May, resulting in a 200-fold decrease in datom concentration by June and early July (Table 3). Bacterial activity is suppressed during the bloom due to low temperature and substrate levels (Pomeroy \& Deibel 1986, Pomeroy et al. 1991). Phagotrophic and mixotrophic organisms are found in all seasons, though they predominate in the summer and fall as components of the microplankton and nanoplankton communities (Stoecker et al. 1989, Paranjape 1990). In our samples, unarmored dinoflagellates and ciliates together made up 12 and $9 \%$ of the cell numbers in the summer and fall, respectively (Table 3). Thus, bacterial numbers and heterotrophic flagellate biomass track the seasonal cycle of water temperature, which peaks in the late summer and early fall (Powell et al. 1987). In the late fall and winter, single-cell diatoms become abundant (McKenzie unpubl.), most likely in response to increased vertical transport of essential, inorganic nutrients due to destabilization of the water column.

The seasonal succession of phytoplankton and microbes is reflected in the changing composition of the faeces of Oikopleura vanhoeffeni and Calanus finmarchicus. Diatoms are the primary component of both animals' faeces in the winter and spring (Fig. 21), especially chain-forming Skeletonema costa- 

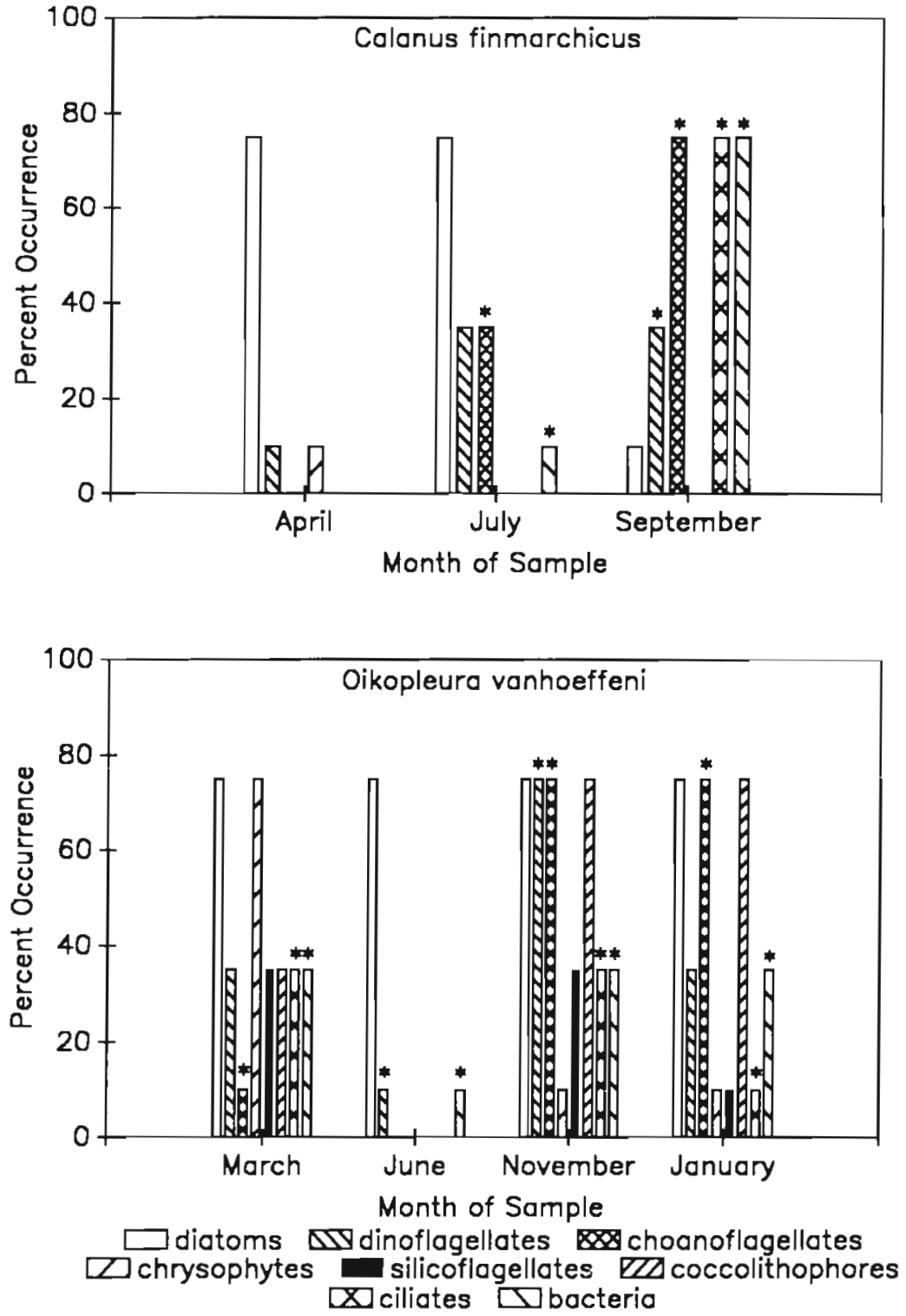

Fig. 21 Oikopleura vanhoeffeni and Calanus finmarchicus. Percent occurrence in the fields viewed per faecal pellet of phytoplankton species within general taxonomic groups at each sampling date. 'At least 1 identi-

fiable heterotrophic species was found in this group.

tum, Chaetoceros spp., Thalassiosira spp. and Fragillariospis spp. (Figs. 1, 3 \& 17). An assortment of heterotrophic nanoplankton species (ciliates, choanoflagellates and gymnodiniods) fill the faeces in the fall (Figs. 9-16 \& 21) Also abundant are amorphous mucous blobs which may be the remains of soft-bodied plankters or marine snow. The large numbers of broken diatoms in the faeces in summer (Figs. 5 \& 21), the few intact diatoms found in the water column (Table 3), and the large number of flocs present in the water (pers. obs.) suggest that both $O$. vanhoeffeni and $C$. finmarchicus are feeding on marine snow derived from fragmented diatoms. We have not attempted to quantify the relative importance of armored vs unarmored or autotrophic vs heterotrophic plankters as a food source for copepods and appendicularians.

\section{A changing food web: links to the microbial loop}

The faecal pellet contents of Oikopleura vanhoeffeni and Calanus finmarchicus follow a similar pattern. They are filled with predominately large $(>20 \mu \mathrm{m})$ autotrophic species in the spring and heterotrophic nanoflagellates and bacteria in the fall (Fig. 21), thus showing seasonal shifts in the zooplankton food web structure (Fig. 22). The inclusion of a variety of taxonomic groups and the ingestion of both autotrophic and heterotrophic species at all sampling dates (Fig. 21) confirms oikopleurids' role as a 'generalist' suspension feeder. A potential seasonal change from the flux of opal due to diatoms in $O$. vanhoeffeni faeces in the spring (Fig. 21) to opal and calcite due to coccolithophorids in the fall and winter faeces occurs (Fig. 21).

The surprisingly high content of bacteria (Figs. 10 \& 21) and heterotrophic nanoflagellates in freshly egested fall Calanus finmarchicus faeces raises the question of the validity of existing conceptual models of the classic food chain, from diatoms to copepods to fish, and suggests it is time to look for mechanisms of how this consumption of bacteria and nanoplankton takes place. Our observations indicate that $C$. finmarchicus ingests non-phytoplanktonic, 'colorless' food particles, generally overlooked in laboratory feeding studies and energy flow models. Marine snow is absent during the spring, but makes up 36 and $7 \%$ of total particles in the summer and fall, respectively (Table 3). Since these aggregates are large $(\geq 50 \mu \mathrm{m})$, they along with attached bacteria and nanoplankters may be ingested by $C$. finmarchicus, incidentally creating an avenue of vertical flux of bacterial biomass. This could also help explain the controversy over external vs internal pellet decay (Honjo \& Roman 1978, Gowing \& Silver 1983, Alldredge et al. 1987)

Previous studies have shown that Calanus finmarchicus is an indiscriminate, raptorial feeder, ingesting 


\section{CLASSIC FOOD WEB}

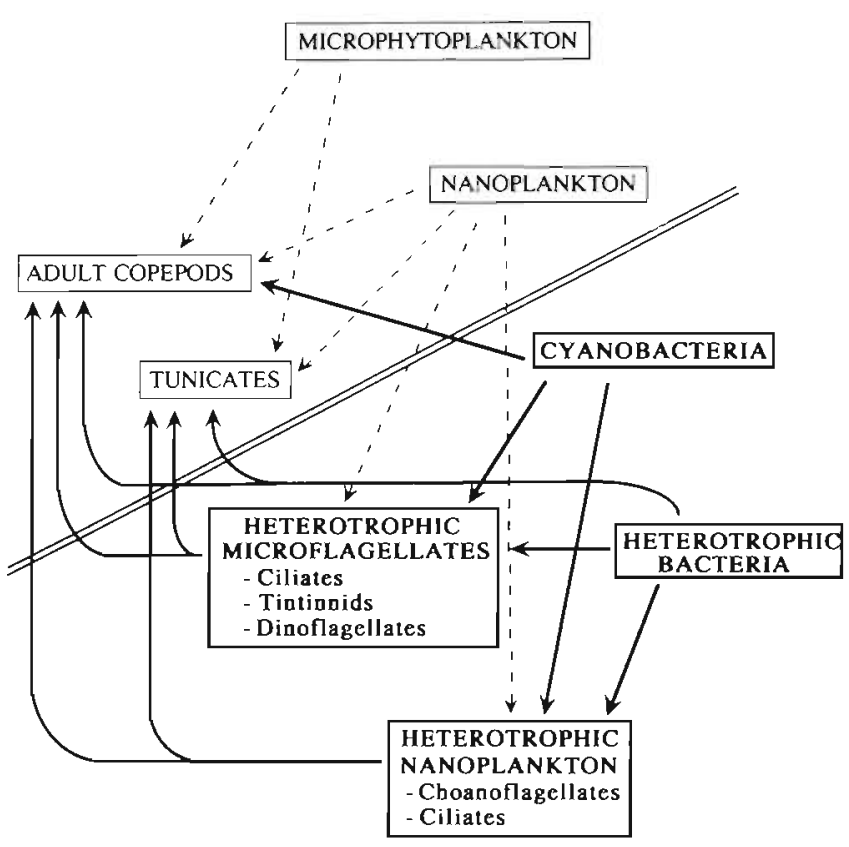

\section{MICROBIAL LOOP}

Fig. 22. Model of zooplankton food web. To the left of the double line and the dashed lines is the classic, diatom-based food web predominant in the spring. To the right of the double line and the bold lines is the microbial loop predominant in the fall. Note: Presumably a line should connect cyanobacteria with tunicates, though no evidence of this was found in our study due to the difference of habitats of

Oikopleura vanhoeffeni $\left(0^{\circ} \mathrm{C}\right)$ and cyanobacteria $\left(\geq 6^{\circ} \mathrm{C}\right)$

those particles present in greatest abundance (Cowles 1979, Ishimaru et al. 1988). Particles < $10 \mu \mathrm{m}$ have been found in C. finmarchicus faeces (Huntley 1981, Ishimaru et al. 1988), indicating that although they are not able to filter particles of this size efficiently (Nival \& Nival 1976), they may be ingested when they are abundant and/or trapped within marine snow aggregates. There are reports of copepods and euphausiids eating ciliates, tintinnids, choanoflagellates, heterotrophic dinoflagellates and coccolithophorids (Berk et al. 1977. Honjo \& Roman 1978, Turner 1984, Marchant \& Nash 1986, Tanoue \& Hara 1986, Ishimaru et al. 1988), implying direct removal of biomass from the microbial loop. In the fall samples from our study, heterotrophic nanoflagellates and bacteria were found in ca $75 \%$ of the fields viewed per pellet while autotrophic diatons, dinoflagellates and cyanobacteria were found in ca $35 \%$ of the fields viewed per pellet (Fig. 21), indicating the seasonal importance of the microbial loop to copepods.

Azam et al. (1983) defined the microbial loop as the interaction between bacteria, flagellates and micro- zooplankton. Choanoflagellate remains were found in the faeces of both Oikoplleura vanhoeffeni and Calanus finmarchicus (Figs. 8, 11 \& 21). These nanoplankton are considered to be important bacteriovores (Sherr et al. 1986) and represent a direct link between macrozooplankton and the microbial loop. The lorica was frequently broken in our samples and the remains were often difficult to recognize. This fragility may explain the relatively few reports of choanoflagellate remains in fecal pellets of macrozooplankton.

Heterotrophic dinoflagellates are another important grazer on bacteria and phytoplankton and are an important food source for copepods (Klein Breteler 1980). Protoperidinium depressum has been reported to feed on bacteria (Lessard \& Swift 1985), and many unarmored dinoflagellates are phagotrophic and form important links in food chains (Kimor 1981, Odate \& Maita 1990). Both P. depressum (Fig. 7) and unarmored dinoflagellates were found in the faecal pellets of Calanus finmarchicus and Oikopleura vanhoeffeni.

It is axiomatic that ciliates and phagotrophic protozoans represent the main link between microheterotrophs and copepods (Porter et al. 1979, Sherr et al. 1986). However, our observations indicate that both copepods and appendicularians are able to feed on bacteria, heterotrophic nanoflagellates and ciliates (Figs. 8 to 11), and thus are capable of mediating a flow of energy out of the microbial loop

Acknowledgements. We thank $\mathrm{G}$. Chaisson and the dive team from the Ocean Sciences Centre and $M$. Riehl for help in collecting animals. We also thank C. Emerson (Biology Department of Memorial University) for the use of the scanning electron microscope and J. Rich for computer assistance. This work was supported by an Operating Grant to D. Deibel from NSERC, and by a NSERC Strategic Grant to Deibel et al. (COPE: Cold Ocean Productivity Experiment). This is Ocean Science Centre contribution number 153.

\section{LITERATURE CITED}

Alldredge, A. L., Gotschalk, C. C., Macintyre, S. (1987). Evidence for sustained residence of macrocrustacean fecal pellets in surface waters of southern California. Deep Sea Res. 34(9): 1641-1652

Azam, F., Fenchel, T., Field, J. G., Gray, J. S., Meyer-Reil, L. A. Thingstad, F. (1983). The ecological role of water-column microbes in the sea. Mar. Ecol. Prog. Ser. 10: 257-263

Berk, S. G., Brownlee, D. C., Heinle, D. R., Kling, H. J., Colwell, R. R. (1977). Ciliates as a food source for marine planktonic copepods. Microb. Ecol. 4: 27-40

Booth, B. C., Lewin, J., Norris, R. E. (1982). Nanoplankton species predominant in the subarctic Pacific in May and June 1978. Deep Sea Res. 29 (2A): 185-200

Burkill, P. H., Mantoura, R. F. C., Llewellyn, C. A., Owens, N. J. P. (1987). Microzooplankton grazing and selectivity of phytoplankton in coastal waters. Mar. Biol. 93: 581-590

Cowles, T. J (1979). The feeding response of copepods from 
the Peru upwelling system: food size selection. J. mar. Res 37(3): $601-622$

Deibel, D., Lee, S. H. (1992). Retention efficiency of submicrometer particles by the pharyngeal filter of the pelagic tunicate Oikopleura vanhoeffeni. Mar. Ecol. Prog Ser. 81: 25-30

Fenchel, T (1988). Marine plankton food chains. Ann. Rev. Ecol. Syst. 19: 19-38

Gowing, M. M., Silver, M. W. (1983). Origins and microenvironments of bacteria mediating fecal pellet decomposition in the sea. Mar. Biol. 73: 7-16

Harbison, G. R., McAlister, V. L. (1979). The filter-feeding rates and particle retention efficiencies of three species of Cyclosalpa (Tunicata, Thaliacea). Limnol. Oceanogr. 24: $875-892$

Hoepfner, N., Haas, L. W. (1990). Electron microscopy of nanoplankton from the North Pacific central gyre. J. Phycol. 26: $421-439$

Hollibaugh, J. T., Booth, J. A. (1981). Observations on the dynamics and distribution of phytoplankton and primary production on the Grand Banks in the 1980 season. In: Grand Banks oceanographic study. Mobil Oil Canada. St. John's, Newfoundland

Honjo, S., Roman, M. R. (1978). Marine copepod fecal pellets: production, preservation and sedimentation. J. mar. Res. $36\{1\}: 45-57$

Huncley, M. (1981). Nonselective, nonsaturated feeding by three calanid copepod species in the Labrador Sea. Limnol. Oceanogr 26(5): 831-842

Ishimaru, T., Nishida, S., Marumo, R. (1988). Food size selectivity of zooplankton evaluated from the occurrence of coccolithophorids in the guts. Bull. Plankton Soc. Jap. 35(2): $101-114$

Kimor, B. (1981). The role of phagotrophic dinoflagellates in marine ecosystems. Kieler Meeresforsch., Sonderh. 5: $164-173$

Klein Breteler, W. C. M. (1980). Continuous breeding of marine pelagic copepods in the presence of heterotrophic dinoflagellates. Mar. Ecol. Prog. Ser. 2: 229-233

Lessard, E. J., Swift, E. (1985). Species-specific grazing rates of heterotrophic dinoflagellates in oceanic waters, measured with a dual-label radioisotope technique. Mar. Biol. 87: 289-296

Marchant, H. J., Nash, G. V. (1986). Electron microscopy of gut contents of faeces of Euphausia superba Dana. Mem. natn. Inst. polar Res., Tokyo Spec. Issue 40: 167-177

Marshall, H. G. (1984). Phytoplankton distribution along the eastern coast of the USA. V Seasonal density and cellvolume patterns for the northeastern continental shelf. J. Plankton Res. 6(1): 169-193

Marshall, H. G., Cohn, M. S. (1983). Distribution and composition of phytoplankton in northeastern coastal waters of the United States. Estuar. coast. Shelf Sci. 17.119-131

Marshall, S. M., Orr, A. P. (1955). On the biology of Calanus finmarchicus. VIII. Food uptake, assimilation and excretion in adult and stage $V$ Calanus. J. mar. biol. Ass. U.K. 34: $495-529$

Michaels, A. F., Silver, M. W. (1988). Primary production, sinking fluxes and the microbial food web. Deep Sea Res. 35(4): $473-490$

Mullin, M. M. (1983). In situ measurement of filtering rates of the salp Thalia democratica on phytoplankton and

This article was submitted to the editor bacteria. J. Plankton Res. 5: 279-289

Murphy, L. S., Haugen, E. M. (1985). The distribution and abundance of phototrophic ultraplankton in the North Atlantic. Limnol. Oceanogr. 30(1): 47-58

Nielsen, T G. Richardson, K. (1989). Food chain structure of the North Sea plankton communities: seasonal variations of the role of the microbial loop. Mar. Ecol. Prog. Ser. 56: $75-87$

Nival, P., Nival, S. (1976). Particle retention efficiencies of an herbivorous copepod, Acartia clausi (adult and copepodite stages): effects on grazing. Limnol. Oceanogr. 21(1): $24-38$

Odate, T., Maita, Y. (1990). Phagotrophic grazing by dinoflagellates on diatoms during the spring phytoplankton bloom in Funka Bay. Bull. Plankton Soc. Jap. 36(2): 142-144

Paranjape, M. A. (1990). Microzooplankton herbivory on the Grand Bank (Newfoundland, Canada): a seasonal study. Mar. Biol. 107: 321-328

Pomeroy, L. R., Wiebe, W. J., Deibel, D., Thompson, R. J., Rowe, G. T., Pakulski, J. D. (1991). Bacterial responses to temperature and substrate concentration during the Newfoundland spring bloom. Mar. Ecol. Prog. Ser. 75: 143-159

Pomeroy, L. R., Deibel, D. (1986). Temperature regulation of bacterial activity during the spring bloom in Newfoundland coastal waters. Science 233: 359-361

Porter, K. G., Pace, M. L., Battey, J. F. (1979). Ciliate protoroans as links in freshwater planktonic food chains. Nature, Lond. 277: 563-565

Powell, J. C., Dabinett, P. E., Gow, J. A. (1987). An annual cycle of abundance and activity of heterotrophic bacteria and abundance of hydrocarbonoclastic bacteria in Newfoundland coastal water. Can. J. Microbiol. 33: 377-382

Sherr, E. B., Sherr, B. F., Paffenhofer, G-A. (1986). Phagotrophic protozoc as food for metazoans: a 'missing' trophic link in marine pelagic food webs? Mar. Microb. Food Webs 1(2): $61-80$

Smayda, T (1980). Phytoplankton species succession. In Morris, I. (ed.) The physiological ecology of phytoplankton. University of California Press, Berkeley

Stoecker, D. K., Taniguchi, A., Michaels, A. E. (1989). Abundance of autotrophic, mixotrophic and heterotrophic planktonic ciliates in shelf and slope waters. Mar. Ecol. Prog. Ser. 50: 241-254

Tanoue, E., Hara, S. (1986). Ecological implications of fecal pellets produced by the Antarctic krill Euphausia superba in the Antarctic Ocean. Mar Biol. 91.359-369

Turner, J. T (1984). Zooplankton feeding ecology: contents of fecal pellets of the copepods Eucalanus pileatus and Paracalanus quasimodo from continental shelf waters of the Gulf of Mexico. Mar. Ecol. Prog. Ser. 15: 27-46

Urban, J. L., Deibel, D., Schwinghamer, P. (in press). Seasonal variation in the densities of fecal pellets produced by the pelagic tunicate Oikopleura vanhoeffeni and the copepod Calanus finmarchicus. Mar. Biol.

Utermöhl, H. (1958). Zur Vervollkommnung der quantitativen Phytoplankton-Methodik. Mitt. int. Ver. theor. angew. Limnol. 9: 1-38

Veldhuis, M. J. W., Colijn, F., Venekamp, L. A. H., Villerius, L. (1988). Phytoplankton primary production and biomass in the western Wadden Sea (the Netherlands): a comparison with an ecosystem model. Neth. J. Sea Res. 22(1): $37-49$

Manuscript first received: October 21, 1991

Revised version accepted: May 5, 1992 